FILE COPY

DO NOT REMOVE

$213-74$

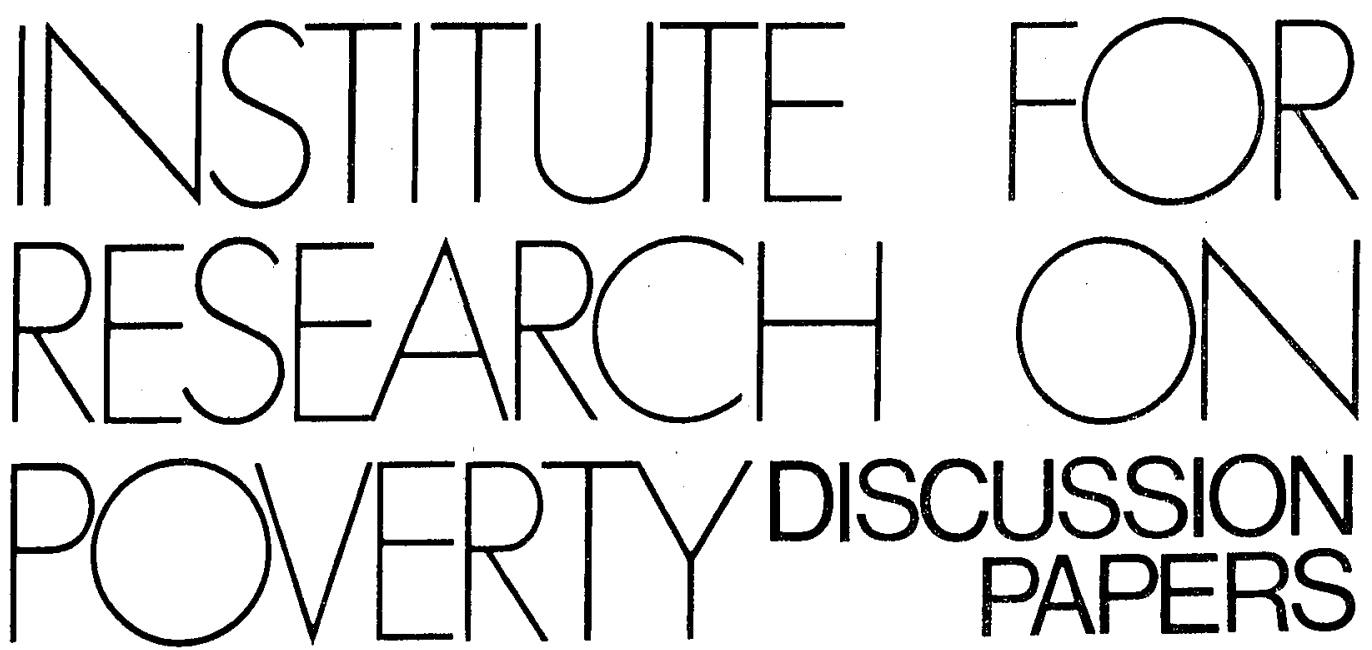

ASSUMPTIONS OF SOCIAL MOBILITY RESEARCH IN THE U.S.: THE CASE OF OCCUPATIONAL STATUS

David L. Featherman

F. Lancaster Jones and

Robert M. Hauser

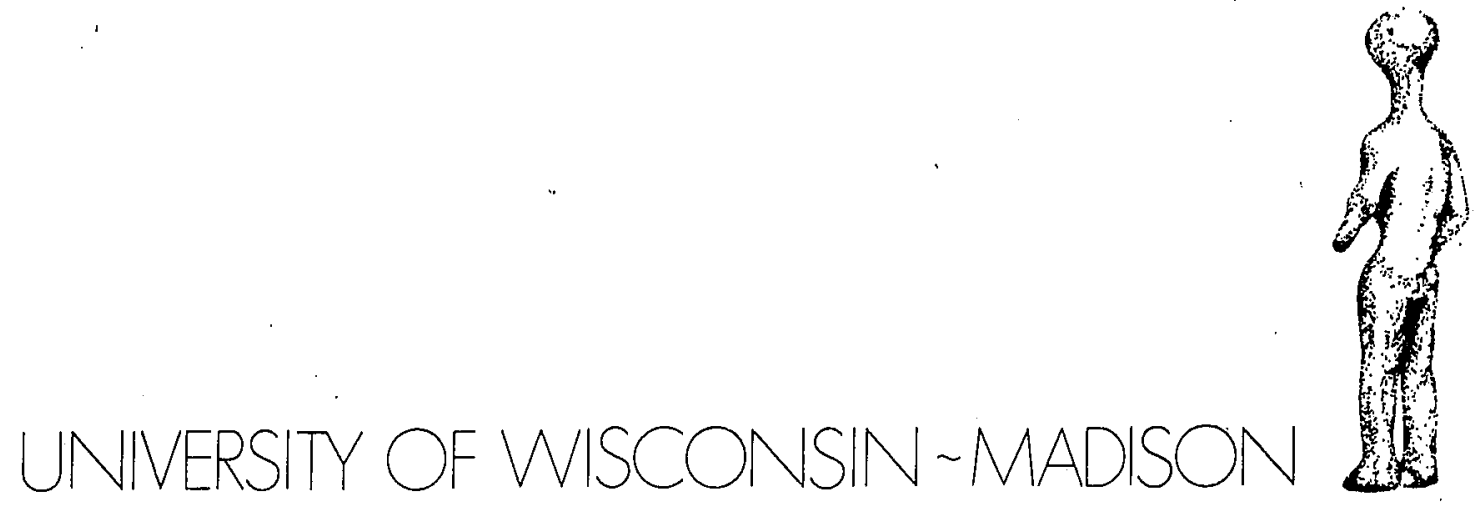




\section{ASSUMPTIONS OF SOCIAL MOBILITY RESEARCH IN \\ THE U.S.: THE CASE OF OCCUPATIONAL STATUS}

David L. Featherman

F. Lancaster Jones*

and

Robert M. Hauser

September 1974

*Australian National University

This research was carried out under grants from the National Science Foundation (GI-31604X1), the American College Testing Program, and institutional support from the College of Agricultural and Life Sciences, Institute for Research on Poverty, and Center for Demography and Ecology. We thank Professor Donald Treiman for granting us early access to his prestige scale. Computations were carried out with the aid of Hernando Gomez-Buendia, Armona Livneh, John Koeffel and R. Blair Wheaton. A version of this paper was delivered at the International Conference on Theory and Research of Social Structure and Mobility, Institute of Philosophy and Sociology, Polish Academy of Sciences, Jablonna, Poland, March 1974. 
This paper examines the theoretical and empirical basis for comon rank-orderings of occupational roles by raters throughout the world. From an illustrative comparison of occupational stratification in Australia and the United States we conclude tentatively that (1) commonalities in the socioeconomic characteristics of occupational roles provide the basis for Interplace consistencies in "prestige" scores, (2) the structure of occupational mobility in the U.S. and Australla is largely similar, (3) this similar structure of occupational stratification manifests a common socioeconomic process which defines a (the?) major component of occupational mobility in capitalist, industrial (only?) societies. We infer that "prestige" scores for occupations are error-prone estimates of the socioeconomic statuses of occupations. 
Recent commentaries on mobility research within the United States (Haller and Portes, 1973; Featherman, Hauser, and Sewe11, 1974) have noted the prominent influence of Blau and Duncan (1967) on both the conceptualization and the conduct of American stratification inquiries. The 1mpact of these approaches has transcended academe to influence the structuring of public policy questions on social and economic inequalities in the U.S. Jencks in IREQUALITY (1972), for example, draws generously from THE AMERICAN OCCUPATTONAL STRUCTURE (B1au and Duncan, 1967), from later extensions of that work (Duncan, Featherman, and Duncan, 1972), and from the pioneering work of Sewell and his associates on the process of status attainment (Sewell, Haller, and Ohlendorf, 1970; Sewel1 and Hauser, 1972). As the influence of the Duncan and Sewell approaches is videly appreciated, we shall not dwell upon it here. However, inasmuch as these perspectives pervade a broad sweep of American studies of inequality and mobility, ${ }^{1}$ and in view of the increasing adoption of similar sociological approaches in comparative mobility researches at the national level (cf. Featherman et al., 1974), it is useful to review assumptions of the status attainment "schoo1." In this paper we address assumptions about occupational status and mobility which critics, friendly and otherwise, find problematic or Ilmiting.

Some American sociologists lament the preponderance of occupation, and particularly of occupational status, in studies of inequality and social mobility. Pease, Form, and Rytina (1970) ask why, after nearly eighty years of attention to these fundamertal issues of American society, analyst forsake power and economic inequalities, devoting nearly exclusive attention to the measurement of occupational status. However, few sociologists would deny the central place of occupational roles within the structure 
of industrialized societies or the linkage of individuals to the society through such roles. These relationships involving occupations are especially clear in capitalist economies (Parkin, 1971:20), with high proportions of the population employed and where about 85 percent of total income derives from salaries, wages, and self-employment. Moreover, if one conceives of "power" as "control over resources" (cf. Titmuss, 1962; Parkin, 1971; Weber, 1958), then studies of social inequality and mobility in the U.S., framed as they often are in terms of occupational mobility, tap into the major stratifying process, ylelding information simultaneously (albeit, indirectly) on status power, economic power, and political (authority) power.

If the structure of capitalist industrial societies justifies the focus on occupations, then what justifies the use of prestige and socioeconomic metrics to scale occupations and to measure social mobility qua occupational stratification and inequality? There is mounting evidence in the U.S. and elsewhere that the hierarchical structure underlying occupational roles is largely socioeconomic. Students of social inequality acknowledge the cross-validated evidence for a hierarchy of occupational prestige. This occupational structure essentially is invariant across spans of several decades, among societies and regions, among the soctocultural characteristics of rankers, and over dimensions of ranking (Hodge, Treiman, and Rossi, 1966; Hodge, Siege1, and Rossi, 1966; Siege1, 1970). Undeniably, American (and probably other) studies represent a congeries of interpretations of prestige, both on the part of the study designers and on that of the rankers of occupational titles (cf. Reiss, 1961:10-42). We would not dispute an interpretation of the emergent prestige ranking as a 
hierarchy of desirability rather than of prestige, in its strictly interpreted classical sense (Goldthorpe and Hope, 1972:30-35), for the social organization of modern capitalist societies (and perhaps others as well) may preclude normatively prescribed prestige groups (viz., symbolically legitimated groups, with patterned relaticnships of deference, acceptance, and derogation) except at the most micro-social levels. However, to agree with this interpretation is not to concur with those who assert that such a state of affairs is theoretically uninteresting (cf. Goldthorpe and Hope, forthcoming:2.7). Our paper examines this argument and the evidence. We first address the question of how populations of raters structure occupations in hierarchical space. To put it another way, what underlies occupational inequality, as popularly evaluated? Evidence accumulated most recently in Britain (Goldthorpe and Hope, forthcoming) joins that available for the Untted States (Reiss, 1961; Siege1, 1970) to indicate that the dimensions underlying occupational inequality in the minds of popular raters are manifold, only some of which correspond to the classical, sociological conceptions of prestige (see Goldthorpe and Hope, 1972:27-33 for a review of this evidence). Despite the evidence that occupational "prestige" rests upon a congeries of dimensions, the common core and dominant dimension of occupational status is socioeconomic in nature. In the U.S., when an individual is querted as to why he or she wants to change jobs, the most typical reasons offered are socioeconomic (e.g., ifinancial, educational reasons) rather than ones indicative of the social prestige of the occupations (Reiss, 1961:29-30). Or, when asked to account for the fact that some occupations are ranked high and others low in social standing, raters again give socioeconomic reasons as the major factors (Reiss, 1.961:30-31). 
It is not surprising therefore that Duncan finds some 83 percent of the variance in the "prestige" of ninety U.S. occupational titles to represent socioeconomic predictors (Duncan, 1961:124). Furthermore, with the rather stable rank-ordering of occupational education and income in the U.S. (cf. Siege1, 1970:202) one expects and does find near invariance in the ratings of occupational "prestige" over several decades.

The most extensive U.S. studies of occupational prestige are reported by Siegel (1970), who like Duncan finds an overwhelming soctoeconomic basls to occupational prestige. From Siegel (1970:265), one can calculate the following regression equation, relating prestige scores for several hundred U.S. occupations to selected characteristics, each measured in standard form:

$$
\begin{gathered}
\hat{P}=-.026 \mathrm{M}-.061 \mathrm{I}+.543 \mathrm{E}-.097 \mathrm{C}+.018 \mathrm{~S}+.014 \mathrm{~F}-.068 \mathrm{~N}+.422 \mathrm{I} \\
\mathrm{R}^{2}=.812,
\end{gathered}
$$

where $M$ is the percentage of employed males in mfg.; $L$ is percentage of employed males self-employed; $E$ is means education, male ECLF; $C$ is percentage of employed males urban; $S$ is percentage of male ECLF in South; $F$ is percentage of ECLF female; is is percentage of male ECLF Negro; and I is mean income, male ECLF. The Beta coefficients indicate the clear dominance of occupational education and income. Contrary to the thesis of Svalastoga (1972) that occupational authority as well as occupational education comprise the core of occupational prestige, the crude indicator of authority, L (percentage of males self-employed), is a dismal predictor of prestige, once having controlled for $E$ and $I$. Siegel argues that the deviations of prestige ratings for occupations from a strictly socioeconomic regression line bespeak explicable, "true" prestige deviations-- 
i.e., those titles enjoying higher or lower social standing than their occupational education and income levels would imply. Still, he finds few measures which explain this "true" prestige variance; note for example, that the Beta coefficients in the regression above for the percentages female or Negro [which we might interpret as indicating the effects of social honor] are quite small.

For Britain, Golathorpe and Hope offer cross-validating evidence for the socioeconomic basis of occupational prestige (Goldthorpe and Hope, forthcoming). On the basis of earlier research one can expect that the newest popular estimates of the social standing of occupations in Britain will correlate highly with those in the U.S., and for the British sample the emergent "prestige" hierarchy is a linear combination (to the extent of 97 percent of its variance) of four rating dimensions: standard of 1iving, power and influence, qualifications, and value to society. (Goldthorpe and Hope do not report the covariances necessary to compute a regression of the prestige scale on the four dimensions, although the correlations among the dimensions indicate that "qualifications" and "power and influence" are the most central components. These data are consistent with the propositions of Svalastoga [1972]. regarding the determination of occupational prestige.)

While Goldthorpe and Hope (forthcoming:2.11) are dismayed by the sociological potential of this congruity between two or more societies in the structure of occupational inequality, we find this fact to be of some substantial theoretical import. We shall elaborate more on this interpretation in later discussion. Suffice to say here that people perceive rather accurately that professional and administrative occupations, by 
their very definition or organization, call for the exercise of greater authority and control and apparently require for their exercise native and trained capacities and personality traits which craft or operative occupations, by their organization, do not (in degree or kind). That the organization of occupations across societies (at least of an industrialized type) is so similar and that persons in them, regardless of their social circumstances, perceive this organization as "socially desirable" (i.e., normative in an existential sense, rather than a legitimatory one) is not without sociological interest.

Additionally, it may be the case that the congruity of ranking and of the basis for that ranking of occupations across societies devolve from sources complementary to the similarity of the organization of occupations in industrial, and especially capitalist, economies. To examine this possibility we inquire about the structure of social qua occupational mobility in the United States. We ask if the basis on which such mobllity occurs is unique or common among capitalist, industrial societles. Our provisional answer is that it is common in large measure, and that the basis of this mobility is socioeconomic. Again we find this observation to be interesting sociologically, but also it sustains the validity of studying social mobility qua movement among categories of occupational socioeconomic status, a basic assumption in American mobility research. We turn now to the evidence.

In a rarely cited publication, Klatzky and Hodge (1971) have demonstrated that the pattern of occupational mobility for the U.S. is ordered according to the socioeconomic distances among occupational categories. Applying canonical correlation techniques to a 17-category classification 
of extended major occupation groups in the Blau and Duncan data, Klatzky and Hodge conclude that the socioeconomic scaling used by Blau and Duncan captured the essential relationship in both inter- and intragenerational mobility. ${ }^{2}$ The canonical correlations were quite close in magnitude to the product-moment correlations reported by Blau and Duncan and the canonIcal welghts for the occupational variates correlated highly with aggregate occupational education and income. Furthermore they reaffirmed that the relative statuses of occupational categories have remained constant, at least over the period of time encompassed by the OCG (Occupational Changes in a Generation) data. For the United States, it would seem that (1) the structure of occupational hierarchies is fundamentally socioeconomic, (2) that this structure in its relationships of relative super- and subordination in a socioeconomic sense has remained constant (at least) within this century, and (3) the major dimension of social distance on which mobility is conducted in the States is socioeconomic.

While these observations are themselves interesting to the sociologist, they would become even more so were we able to demonstrate consistencies across societies and/or systematic societal variations in these elements of stratification systems. In fact, research underway by Treiman and by Featherman and Hauser in the U.S. joins that in other nations which works toward this end. Here we wish to report on similarities uncovered in our reanalysis of data for Australia, kindly provided for this purpose by Professor F. L. Jones and his colleagues. These data are those from the 1965 mobility survey conducted among adult male workers. Our purpose in reanalysis is to effect more comparable analyses than were possible earlier, espectally prior to Jones' (1971) comparison of U.S.-Australian path models. ${ }^{3}$ 
The following comparison rests upon a reconciliation of the occupational detail in the two data sets into a single classification at the level of ten major occupation groups and into (nominally) the same educational categories. We would note that while now the two surveys are substantially more comparable with respect to the classification of educational and occupational information, there remain conceptual differences between the two studies. The most marked is the definition of "father's occupation," which in the OCG data is given by the occupation of father at the son's age 16, and which in the Australian data (AivU) is father's current occupation (circa 1965) or longest job (if deceased or not then at work). Table 1 summarizes the inter- and intragenerational mobility tables in the appendix to this paper. Briefly, in all three mobility matrices we observe greater net mobility (structural mobility, as given in the marginal distributions) in the U.S. than in Australia, coupled with somewhat greater observed (gross) mobility, especially in career mobility. Were we to subtract minimum from observed mobility to calculate "circulation" mobility in the fashion of Broom and Jones (1969) we would find greater circulation mobility in Australia than in the U.S., except in the case of career mobility where these rates are nearly identical (compare Broom and Jones, 1969). If we take the model of complete independence of origins and destinations as a norm for comparison, the mobility indices of Table 1 argue for no real societal difference in the relationship of observed to expected mobility (which is really a ratio of "clrculation" mobility observed to "circulation" mobility expected on the model of complete independence), save in the case of career mobility. In the latter instance, there is some more predictability, or rigidity, in the Australian Intragenerational transition matrix. 
Are the ANU and OCG matrices the same or different? Table 2 offers some insight into the question of whether the bivariate mobility patterns bespeak two societies with one mobility regime or with two different ones. We have applied log-linear models developed by Professor Leo Goodman (1972) to a three-dimensional data matrix for each of the three mobility matrices. Dimension one is occupation of origin (father's or first occupation), dimension two is occupation of destination (first or current occupation), and dimension three is place (Australia or U.S.); overall each matrix is 10x10x2. The data are completely nominal, and the purpose is to apply models of Interest to the end of predicting or estimating the observed frequencies in each matrix. Goodness of fit of a model is given by testing against Chi-square. Table 2 reports on two models: model A estimates the frequencies on the assumption that differences in mobility between the two places are soley a function of different structure, as given in the origin and destination marginals; model $B$ estimates the frequencies on the assumption of different marginals but it also assumes that outflow and inflow relationships (i.e., mobility relationships between origins and destinations) are the same in both places. It is important to note that a significant Chi-square value for the fit of this model indicates that model $B$ does not fit the data well, implying that mobility patterns in the two places are not the same.

Table 2 is clear about the fit of model A: there is far more to the pattern of mobility in the two societies than is given in the fact of their differing (marginal) structures. Actually, we have no great interest In mode1 A except as it serves as a baseline for assessing the fit of model $B$, which hypothesizes (as null) that there is no difference in mobility 
regimes. We must reject null (no difference), as the deviations of observed from expected frequencies are statistically signiflcant. This means that in each of the three mobility matrices there are interactions which are attributable to place, holding constant differences in (marginal) structure and the additive mobility effects of place. However, it is important to note that the departures of the observed from expected frequencies under model $B$ are but a small percentage of both the total Chi-square for each matrix and the values under model A. In fact, Chi-square values for net inter-place differences in mobility $(262.6,386.4$, and 452.4 from Table 2) are but some 5 percent of the Chi-square under model A; therefore, about 95 percent of the "variance" in each matrix, net of the inter-place differences stemming from their marginals, is attributable to additive effects, i.e., place-constant mobility patterns. So, despite a significant interplace difference, the significant effect of inter-place similarity is dominant.

We now block the origin categories for farmers and farm laborers and rerun our log-linear models on the $8 \times 10 \times 2$ matrices for men of nonfarm origin. This strategy reveals a major source of the imperfect fit of model $B$. About 75 percent of the original Chi-square in each of the two intergenerational inter-place matrices and 54 percent of Chi-square in the intragenerational inter-place matrix is a function of the differential effects of farm origins in the two societies' mobility regimes, although the remaining Chi-square indicates a continuing, sometimes significant, but substantively small (4 percent of Chi-square under model A), inter place effect within the nonfarm population.

We conclude from this analysis of contingency tables that the blvarlate process of mobility in Australia and the U.S. in the mid-60s was largely the same, with minor but significant idiosyncratic patterns, originating in the main from the unique mobility patterns for men from farm origins. 
Having established a case for the similarity of stratification as a process in the two societies, we inquire into the foundation of that process. Given our knowledge of the socioeconomic basis of occupational stratification in the United States, it would be surprising were it to be otherwise for Australia.

Tables 3 through 8 report on an extensive examination of the process of stratification as revealed in the AINU and OCG data. We have classified and scaled both data sets equivalently, running correlations and regressions for both the total and nonfarm populations, and altering the analysis by rescaling occupation variables (at the level of major groups) into Duncan's socioeconomic index (1961), Siegel's (1970) new prestige scores, and Treiman's (forthcoming) standard international prestige index. ${ }^{4}$ Since we have expected somewhat greater similarity between societies among the nonfarm origin than among the total male population, we have run separate analyses for these groups.

Table 3 contains interscale correlations for two of the three occupational variables from the basic Blau and Duncan model which we have estimated (in its fully-recursive form) for both societies. By and large, the two prestige scales correlate more highly with each other than does either with the socioeconomic scale. In both societies, the Duncan and Siegel scales are more highly collinear than are the Duncan and Treiman scales, perhaps indicating somewhat less validity in Treiman's version of prestige in both places. Inasmuch as the largest difference between socioeconomic and prestige scales involves the treatment of farm occupational statuses, it is not surprising that the two SES-prestige correlations are higher when calculated over the nonfarm rather than the total population; 
however, there is no change in the Treiman-Siegel correlations. Finally, there are no apparent systematic differences attributable to place in Table 3.

Tables 4 and 5 render product-moment correlations for the five variables of a Blau-Duncan stratification model, along with means and standard deviations. We shall not dwell on these summary statistics, except to note that the correlations for Australia, based on the reconclled major occupation group classification, are much closer to their U.S. counterparts than are the correlations reported by Jones (1971), which rested upon a different educational and occupational classification. Furthermore, for both societies and in each population of both places, the correlations calculated over Duncan's socioeconomic index are unfformly higher than those computed over either of the prestige scales. We shall take advantage of this observation later.

For total men in Australia (Table 6) and in the U.S. (Table 7), the process of stratification, as depicted by occupational variables encoded in any of the three matrics of status, is much the same. Comparing panels $A, B$, and $C$ of standardized regression coefficients within each of Tables 6 and 7 reveals no striking departures from the now famillar relationships in this three-equation stratification model, irrespective of the metric in which occupation is scaled. However, in each of the three equations for both Australia and the U.S., the $R^{2}$ value is higher if we have scaled occupations in units of socioeconomic status rather than in units of prestige (Siegel or Treiman). This finding is consistent with an argument that rests the process of stratification on an underlying socioeconomic base, irrespective of place. 
When we compare societies rather than scales of status (e.g., comparing panels A in Table 6 with panels A in Table 7) we pay closer attention to the panels of metric (raw) regression coefficients rather than those of unstandardized ones. However, among the standardized coefficients the only between-societal difference in the relative importance of various regressors is in the equation for curre.t occupation: In the U.S., education is somewhat more important in the determination of current occupation than is first job, although in Australia these two factors play somewhat equivalent roles. We would jump quickly to the metric estimates for these same equations and report that in raw units of socioeconomic status or prestige, the current occupational returns to education and first jobs in the two places are quite similar. Moreover, in equation lines 5 and 6 of Tables 6 and 7 the most marked intersocietal differences involve the role of father's education in the determination of son's first and current jobs, but It is this parameter whose estimates in both societies are either statistically nonsignificant or nearly zero in absolute size. In these between-place comparisons we find little evidence for earlier conclusions (cf. Jones, 1971) that the processes of stratification in Australia and the U.S. are dissimilar in their fundamental character or in the operation of particular variables.

The men of nonfarm origin in the U.S. and Australia are perhaps most comparable, and they appear in Table 8; we pause to note from the metric coefficients some minor differences in the process of achievement as given therein. From the equation intercepts it is clear that the Americans attain somewhat higher average years of schooling than do the Australians, controlling for background factors. While the Australians typically are 
better able to enter higher status first jobs, U.S. men hold more prestigeous current occupations. Among the regression estimates, we find in equations 4 of panels A and B that Australian father's education is half again as efficacious for son's education as is the case in the States, although In terms of real consequences of this difference, the net advantage to the Australians is trivial. In equations 5 of panels $A$ and $B$ the Australians appear to benefit some 1.6 Duncan score points more than the Americans from equal (net) schooling, while the Americans enjoy a one-unit advantage over their Australian counterpart's current occupational attainments; again this difference is trivial. While the societal differences in the effects of paternal education in equations 5 and 6 are large enough to be significant, the coefficients themselves are elther statistically nonsignificant or negligible in their substantive bearing.

We return to our earlier observation that in both places the correlations for the basic model are higher when run over socioeconomic status than over prestige; additionally, $R^{2}$ values in regression equations for each society are larger when calculated for socloeconomlc variance. These data, which replicate earlier observations within the U.S. (Duncan, Featherman, and Duncan, 1972:45-49), are consistent with the interpretation that prestige scales are fallible indexes of soctoeconomic status. If what underlies the apparent fundamental similarity of social mobilfty among some societies is a socioeconomic process, then to study that process via prestige scales is to misspecify its essence and to err (though not by a large arithmetic factor, given the usually high correlation between scales of prestige and socioeconomic status) in statistical estimation of cause and effect. 5

In taking this interpretation seriously, we have specified the causal model in Figure 1, obtaining the estimates which appear in Table 9 for 
both societies using a technique developed by K. Jöreskog (Jöreskog, Gruvaeus, and Thillo, 1970)。 Essentially Figure 1 represents a factor model in which each of the boxed variables is unmeasured in either of OCG or ANU data but which are reflected in variables for which we have measurements (Indicators). For simplicity we have taken the Duncan and Treiman scores as reflections of each unmeasured occupational variable, and we have estimated the validity of each from the data matrix. In the case of the two education variables, we have assumed a constant validity coefficlent of .966 , based on earlier analysis (SIegel and Hodge, 1968). The estimation procedure conforms to a confirmatory factor model, and Figure 1 assumes all restduals are uncorrelated. If we are correct in asserting that the process of achievement in both the U.S. and Australia Is a socioeconomic one and that prestige scales are fallible indicators of socioeconomic status, we should estimate higher validity coefficients for the Duncan scale reflections than for the Treiman scale variables.

In fact, Figure 1 confirms our expectations, with validities of unity for all Duncan variables in both societies and substantially lower ones for the Treiman variables. The standardized regression estimates in Table 9 do not deviate in their descriptive character from those in Tables 6 and 7 , save for the larger $R^{2}$ values; hence we shall not discuss them.

To conclude our analysis of the structure of social mobility, in its common features, across societies, and to offer additional credibility for our assertion as to its socioeconomic character, we conducted a series of canonical correlation analyses of the societies' mobility tables. In using this technique we have retrenched from the superimposition of structure upon the process of mobility to the point of making such structure problematic. 
We know from our application of log-linear models that the two societies' occupational stratification systems are largely the same. The regression analysis has assumed that the basis of similarity was some common socioeconomic process. Can we establish independent support for this interpretation?

Table 10 gives the canonical weights for the first and second variates for each of the three mobility tables in each soclety; Table 11 reports weights for the first variates in both places from intert and intragenerational mobility tables for the men of nonfarm origins. A summary and interpretation of these variates are contained in Tables 12 through 14 ; It is the latter tables which we shall discuss.

Table 12 establishes that mobility for total men in both societles involves at least two orthogonal variates which yleld canonical correlations of some magnitude. When we compare the canonical correlations for the U.S. and those for Australia with their Duncan score counterparts in Table 4 panel $a$, it is apparent that the maximum correlations for the first varlates exceed the Pearsonian correlations and that there is more vartance in each of these tables than is captured under the assumption of socioeconomic (or prestige) dimensionality. The exception to this interpretation is the U.S., wherein the deviation of the two intergenerational canonical correlations from their socloeconomic, product-moment counterparts is slight. For men of nonfarm origin (compare Table 12 with Table 5 panel a), the canonical correlations for the first variates compare rather favorably in both socleties with the Pearsonian correlations.

That there is dissimilarity in the scaling of the first varlates between societies is evidenced in Table 13, where the Pearsontan correlations of the 
weights of corresponding variates in the two places are reported. These correlation coefficients range from .60 to .96 , with the highest correspondence arising in the intragenerational relationship (rows $D$ and $F$ ). Limiting our attention to men of nonfarm orlgins (lower panel of Table 13), we find cross-socletal correlations in excess of .90 , with the exception of the reflection of father on son's first job $(x=.82)$.

Having achieved a scoring of major occupation group categorles through induction from the mobility matrices, we now attempt to identify the emergent structure of mobility in the two socleties. Table 14 arrays the correlations on the canonically scored varlates with each of Duncan's and Siegel's status scores. If the canonical structure of mobility in either society is essentially a socioeconomic process or a phenomenon of prestige hierarchies, then the correlations should be rather high. If the common core of social mobility in both societies is movement through socioeconomlc rather than prestige space, then in both societies the correlations between the canonical scores and the Duncan scores should be higher than those between the canonical weights and the Siegel scores.

In nearly every comparison, the column involving the Duncan soctoeconomic scores contains higher correlations than the column with S1egel prestige scores. The scorings of the first variates in the U.S. more closely adhere to the occupational hierarchy of socioeconomic status than in Australia, although in both societies it is intragenerational mobility which most nearly approximates a unidimensional, socioeconomic process. For the U.S., the structure of intergenerational mobility to first.jobs seems to entall more than socioeconomic variance, as the reflection of father's occupation on son's first job, and vice versa, have the lowest 
correlations with occupational socioeconomic status. When we look at the correlations run over the nonfarm men, there is little to dispute; the canonical structure of social mobility is given in socioeconomic distance among major occupation group categories.

In closing, we propose that the fundamental core of occupational inequality in the U.S. and other capitalist, industrialized socleties is socioeconomic status, and not occupational prestige. Furthermore, across capitalist industrial (and possibly other) societies the common structure of social mobility is occupational socioeconomic status. We assume that there are idiosyncratic features to each soclety's stratification system, for clearly the U.S.-Australian comparison has yielded evidence of such properties (namely in the mobility patterns associated with men of farm origins). Likewise, we readily acknowledge the variance in any society's process of achievement which stems from non-socioeconomic factors, strictly construed. In the American case, the interaction of race with the socioeconomic components of the basic model and the historically unique pattern of intergenerational mobility of blacks vis-a-vis whites are manifestations of cultural, social, and/or ideological elements of U.S. society which affect the operation of the process of stratification. St111, the basic model of socioeconomic stratiflcation applies to blacks, although in some attenuated form.

We eschew the necessity of some legitimatory, normative system, either within an individual or within a total soclety, for the operation and maintenance of these largely similar socioeconomic processes of stratification. Whether the sociological facts of inequality and stratification in a given place are consensually validated or not, or, whether or not an individual's 
sense of distributive justice accords with these facts, are interesting research questions with import for social change. However, in the final analysis, values may play a relatively minor role, relative to the impact of the economy, in shaping and sustaining the mobility processes in capitalist, industrial nations. Therefore, our research is not offered efther as substantiation for or in refutation of a functionalist theoretic position, as it is usually understood.

We speculate quite tentatively (while similar analyses to those reported herein can be carried out in other places) that concurrence across societies on the hierarchical rating of occupations, and the apparent commonality of socioeconomic distance as the metric of measurement for this ordering, arise from quite similar economic forces of supply and demand which have noticeably and parallel features in capitalist, industrial nations. Furthermore, these same economic relationships of supply and demand define the specific details of the process of stratification--i.e., which variables are to be included in the basic model and the effect parameters among them. Popular evaluations of occupational prestige or desirability conducted in different places mirror the common features of their respective stratification processes, namely their socioeconomic elements.

Rather than fostering uninteresting theoretical questions, the emerging evidence for the cross-societal importance of socioeconomic status (among those places in which such research has been attempted) offers up new lines of Inquiry and speculation. These findings may lead us away from a preoccupation with personal and societal values to a focus on common and uniqu features of institutions--particularly economic and political ones-across societal boundaries and over time. In the spirit of this thought, we would 
hope that stratification research of the kinds reported herein might be implemented in noneapitalist economies. If in such industrialized, noncapitalist societies the major basis of stratification is occupational socioeconomic status, as we provisionally conclude it is in capitalist economies, such a finding would have a profound impact on existing theories of social stratfication. At least for the United States, we are not troubled by the standing assumption that occupational socioeconomic status is the primary basis of mobility. 
FOOTNOTES

${ }^{1}$ Clearly not all current American researches conceive of mobility as a process of achievement, after Duncan and Sewe11. Notable exceptions include the continulng analysis of mobility tables (1.e., Goodman, 1969; MicFarland, 1969, 1970; Fararo, 1973), scrutiny of job vacancy-chains (White, 1970), and dynamic assessments of occupational life histories (Sфrensen, 1973). For a partial overview of major U.S. Inquiries incorporating status attainment approaches, see Duncan et al., 1972:Epilogue.

${ }^{2}$ Klatzky and Hodge report a second canonical variate for the U.S., which they do not interpret. Moreover, Duncan-Jones (1972), independentiy analyzing the OCG and other natfonal mobility data, finds discrepancies between the canonical and least-wquares (ordinary correlations) structures, especia11y for the Eather-to-son's first occupation matrices. These observations demonstrate that social mobility is not purely a matter of socioeconomic processes, although they do not detract from the socioeconomic intepretation of the major common feature of mobility which we advance aubsequently.

3 Jones did not have at his disposal the unit-record tape from the ocG survey as he attempted the earifer comparison of the two stratification systems. Thls precluded computations of metric regressions based on comparabiy coded educational and occupational classirications.

4 rine major group scale scores are as follows:

\begin{tabular}{|c|c|c|c|}
\hline Occupation Group & Duncan & $\frac{\text { Scales }}{\text { Siegel }}$ & Treiman \\
\hline Professional, technteal and kindred & 75 & 60 & 57 \\
\hline Managers, offlctals, proprietors & 57 & 50 & 64 \\
\hline Clerical and kundred & 45 & 39 & 44 \\
\hline Sales and kindred & 49 & 34 & 40 \\
\hline Craft and indred & 31 & 39 & 41 \\
\hline Operatives & 18 & 29 & 33 \\
\hline Service & 17 & 25 & 31 \\
\hline Nonfara 1abor & 7 & 18 & 19 \\
\hline Farmers and farm mgrs. & 14 & 41 & 47 \\
\hline Farm laborers & 9 & 19 & 27 \\
\hline
\end{tabular}


${ }^{5}$ Surely there are analyses in which a purified prestige scoring of occupations makes more sense conceptually than does a socioeconomic scoring. However, in models of status attainment wherein individual-level achievements of economic (earnings), educational, and occupational status are problematic, we argue here that a socioeconomic scoring is preferable. Clearly in adopting a major occupation group classification, we have assumed the theoretical import of skill levels and "head-work/hand-work" distinctions; this is consistent with standing notions about the characteristics of Industrialized societies. By scoring major occupation groups in the metric of socioeconomic status (i.e., aasigning aggregate, groupspecific socioeconomic scores), we uncover two interesting relationships in models of status attainment, estimated over individuals. First, we estimate the relationsinip of individuals' educational achievements (years of schooling) to their occupational levels, based on knowledge of the expected educational (1.e. skills) and earnings, (1.e. performance, productivity) characteristics of average role encumbants. Second, we estimate the relationsipip of individuals' earnings to their occupational levels, based on expectations in the aggregate of the educational and earnings of "typical" role encumbants. Were we to score occupations in the metric of prestige, we would be faced with the theoretical dilemma that prestige is ordinarily thought to be an outgrowth (among other determinants) of education- and wealth-based criteria. 


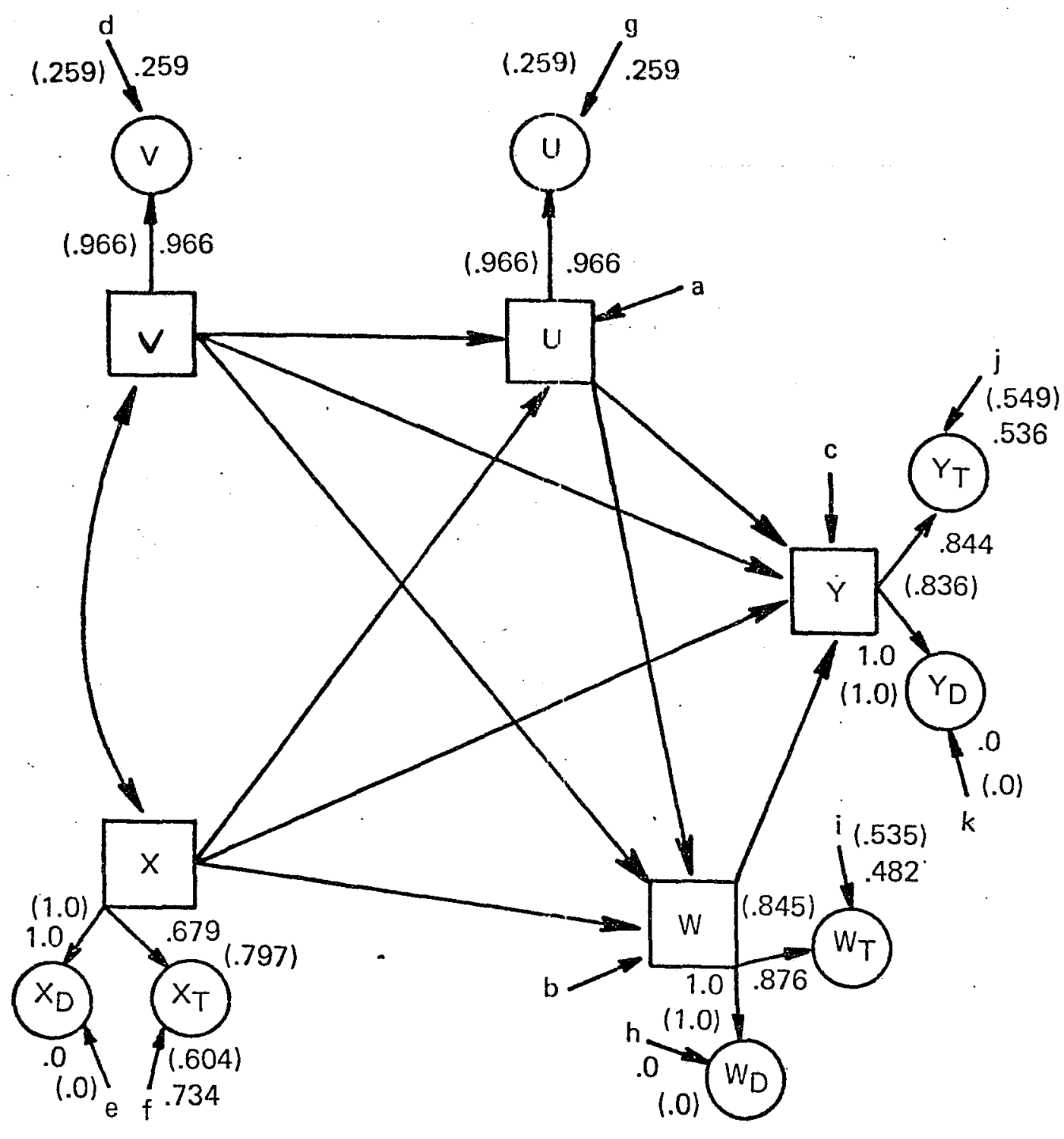

Variables

$\checkmark$ Father's education

$U$. R's education

$X$ Father's status

$X_{D}$ Father's Occ.-Duncan

$X_{T}$ Father's Occ.-Treiman

$W$ First Job Status

$W_{D}$ First Job-Duncan

$W_{T}$ First Job-Treiman

$Y$ Current Occ. Status

$Y_{D}$ Current Occ.-Duncan

$Y_{T}$ Current Occ-Treiman

Figure 1. Confirmatory Factor Model of the Process of Socioeconomic Achievement, U.S. and Australian Men.

Notes: $\square$ Denotes unmeasured variable; $\bigcirc$ denotes measured variable.

For estimates of unmarked paths, see Table 9. Coefficients in ( ) are for. U.S. 
Table 1: Occupational Mobility Statistics for U.S. Men Aged 20-64 in 1962 and Australian Men Aged 20 and Over in 1965

\begin{tabular}{|c|c|c|c|c|}
\hline \multirow{2}{*}{$\begin{array}{l}\text { Type of Mobility } \\
\text { and Soclety }\end{array}$} & \multicolumn{2}{|c|}{ Percent Changing Major } & Occ Group & \multirow{2}{*}{$\begin{array}{l}\text { Mobilitv } \\
\text { Index }\end{array}$} \\
\hline & Minimum ${ }^{a}$ & Observed $^{b}$ & Expected ${ }^{c}$ & \\
\hline \multicolumn{5}{|l|}{$\begin{array}{l}\text { FATHER'S OCC TO } \\
\text { CURRENT OCC }\end{array}$} \\
\hline U.S. & 22.3 & 77.2 & 87.8 & 83.8 \\
\hline AUSTRALIA & 13.7 & 75.0 & 88.2 & 82.3 \\
\hline \multicolumn{5}{|l|}{$\begin{array}{l}\text { FATHER'S OCC TO } \\
\text { FIRST OCC }\end{array}$} \\
\hline U.S. & $44 \cdot 4$ & 79.4 & 90.2 & 76.4 \\
\hline AUSTRALIA & 24.6 & 74.8 & 88.4 & 78.7 \\
\hline \multicolumn{5}{|l|}{$\begin{array}{l}\text { FIRST OCC TO } \\
\text { CURRENT OCC }\end{array}$} \\
\hline U.S. & 32.4 & 72.2 & 88.5 & 70.9 \\
\hline AUSTRALIA & 22.4 & 61.1 & 88.2 & 58.8 \\
\hline
\end{tabular}

avet mobllity; coefficient of dissimllarity comparing row and column marginals.

${ }^{b}$ Percentage off main diagonal.

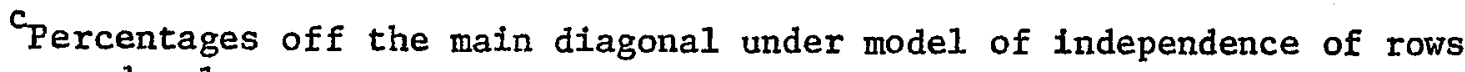
and columns.

$\mathrm{d}_{\text {Mob1lity Index }}=\left(\frac{\text { Observed }- \text { Minimum }}{\text { Expected }- \text { Minimum }}\right)$ 
Table 2: Applications of Log-Linear Models to Mobility Matrices for U.S. Men Aged 20-64 in 1962 and Australian Men Aged 20 and Over in 1965

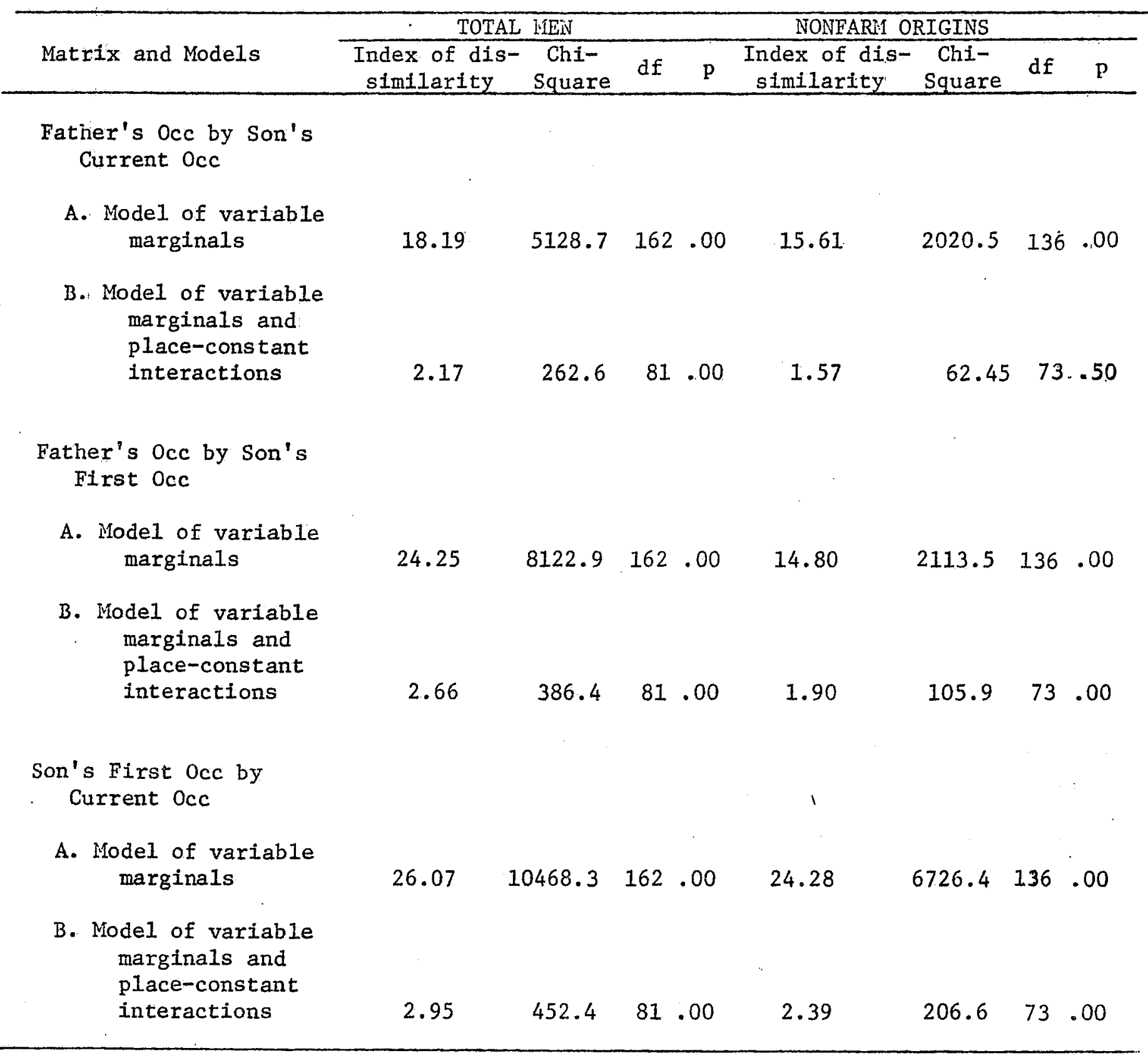


Table 3: Inter-scale Correlations ${ }^{\text {a }}$ Over Major Occupation Groups, Duncan (1961), Siegel (1970), and Treiman (forthcoming) Scores, Australian Men Aged 2.0 and Over in 1965 and U.S. Nen Aged 20-64 in 1962

TOTAL MEN

\begin{tabular}{|c|c|c|c|c|}
\hline & $\begin{array}{l}\text { Fathe } \\
\text { Australia } \\
\end{array}$ & $\begin{array}{l}\text { Upation } \\
\text { U.S. }\end{array}$ & $\begin{array}{r}\text { Current } \\
\text { Australia } \\
\end{array}$ & $\begin{array}{r}\text { Occupation } \\
\text { U.S. } \\
\end{array}$ \\
\hline Duncan-SiegeI & .8265 & .7224 & .8825 & .9013 \\
\hline Duncan-Treiman & .7971 & .6794 & .8358 & .8441 \\
\hline Siege1-Treiman & .9449 & .9404 & .9347 & .9272 \\
\hline
\end{tabular}

NONEARM MEN

\begin{tabular}{|c|c|c|c|c|}
\hline & \multicolumn{2}{|c|}{ Father's Occupation } & \multicolumn{2}{|c|}{ Current Occupation } \\
\hline & Australia & U.S. & Australia & U.S. \\
\hline Duncan-Siege1 & .9341 & .9454 & .9388 & .9467 \\
\hline Duncan-Treiman & .9010 & .9111 & .8853 & .8940 \\
\hline Siegel-Treiman & .9426 & .9373 & .9286 & .9255 \\
\hline
\end{tabular}

${ }^{a}$ Correlations reflect population frequencies as weights. 
Table 4: Coefficients of Correlation for DCG Males Aged 20-64 (above diagonal) and Australian Males Áged 20 and Older (below diagonal), Based on Reconciled Classification of Occupations into U.S. Major Occupation Groups, With Categories Scored in Selected Metrics of Status

(a) Socioeconomic Status (Duncan, 1961) Metric

\begin{tabular}{lccccc|rcr} 
& FAED & FAOCC & EDUC & FJOB & OCC & Mean & Std. Dev. \\
\cline { 2 - 7 } & -- & .501 & .445 & .325 & .298 & 2.27 & 1.55 \\
Father's education & .449 & -- & .426 & .402 & .380 & 28.06 & 18.77 \\
Father's occupation & .502 & .321 & - & .512 & .564 & 3.42 & 1.56 \\
R's education & .286 & .277 & .498 & - & .523 & 26.68 & 20.23 \\
R's first job & .319 & .305 & .516 & .529 & -- & 35.66 & 21.48 \\
R's current occupation- & 2.44 & 28.44 & 3.17 & 29.09 & 34.37 & & \\
$\quad$ Mean & 1.31 & 19.82 & 1.33 & 21.12 & 22.03 & &
\end{tabular}

(b) NORC Prestige (Siege1, 1970) Metric

\begin{tabular}{lccccc|rr} 
& FAED & FAOCC & EDUC & FJOB & OCC & Mean & Std. Dev. \\
\cline { 2 - 6 } Father's education & -- & .360 & .445 & .298 & .261 & 2.27 & 1.55 \\
Father's occupation & .378 & -- & .234 & .219 & .236 & 37.46 & 10.06 \\
R's education & .502 & .212 & - & .472 & .503 & 3.42 & 1.56 \\
R's first job & .243 & .198 & .446 & -- & .444 & 31.58 & 11.82 \\
R's current occupation & .270 & .242 & .460 & .441 & - & 38.28 & 12.08 \\
\cline { 1 - 5 }$\quad$ Mean & 2.44 & 34.38 & 3.17 & 32.22 & 36.77 & & \\
$\quad$ Standard Deviation & 1.31 & 11.48 & 1.33 & 11.84 & 12.64 & &
\end{tabular}

(c) International Prestige (Treiman, forthcoming) metric

\begin{tabular}{lccccc|rr} 
& FAED & FAOCC & EDUC & FJOB & OCC & Mean & Std. Dev. \\
Father's education & -- & .305 & .445 & .283 & .237 & 2.27 & 1.55 \\
Father's occupation & .305 & -- & .219 & .216 & .240 & 42.58 & 11.58 \\
$\mathrm{R}^{\prime}$ 's education & .502 & .198 & -- & .435 & .442 & 3.42 & 1.56 \\
$\mathrm{R}^{\prime}$ 's first job & .230 & .183 & .400 & -- & .371 & 35.52 & 10.98 \\
$\mathrm{R}^{\prime}$ 's current occupation & .230 & .220 & .356 & .384 & -- & 42.77 & 12.98 \\
\cline { 1 - 5 }$\quad$ Mean & 2.44 & 39.78 & 3.17 & 36.47 & 42.41 & & \\
$\quad$ Standard Deviation & 1.31 & 12.76 & 1.33 & 12.41 & 13.96 &
\end{tabular}


Table 5: Coefficients of Correlation for OCG Males Aged 20-64 of Nonfarm Background (above diagona1) and Australian Males Aged 20 and Over of Nonfarm Background (below diagonal) Based on Reconciled Classification of Occupations into U.S. Major Occupation Groups, With Categories Scored in Selected Metrics of Status

(a) Socioeconomic Status (Duncan, 1961) Metric

\begin{tabular}{lccccc|rr} 
& FAED & FAOCC & EDUC & FJOB & OCC & Mean & Std. Dev. \\
Father's education & - & .494 & .419 & .300 & .274 & 2.49 & 1.61 \\
Father's occupation & .468 & -- & .384 & .336 & .337 & 34.10 & 19.32 \\
R's education & .505 & .322 & - & .487 & .562 & 3.69 & 1.50 \\
R's first job & .277 & .270 & .494 & - & .504 & 30.18 & 20.79 \\
R's current occupation & .313 & .301 & .501 & .527 & - & 38.80 & 21.64 \\
\hline$\quad$ Mean & 2.54 & 32.88 & 3.26 & 30.51 & 35.75 & &
\end{tabular}

(b) NORC Prestige (Siege1, 1970) Metric

\begin{tabular}{lccccc|rr} 
& FAED & FAOCC & EDUC & FJOB & OCC & Mean & Std. Dev. \\
Father's education & - & .449 & .419 & .282 & .247 & 2.49 & 1.61 \\
Father's occupation & .454 & -- & .342 & .289 & .291 & 36.87 & 11.17 \\
R's education & .505 & .283 & - & .459 & .514 & 3.69 & 1.50 \\
R's first job & .249 & .240 & .472 & - & .464 & 33.31 & 11.81 \\
R's current occupation & .274 & .274 & .469 & .468 & -- & 39.33 & 12.33 \\
\cline { 1 - 4 }$\quad$ Mean & 2.54 & 35.25 & 3.26 & 32.69 & 37.04 & & \\
$\quad$ Standard Deviation & 1.35 & 11.35 & 1.36 & 11.72 & 12.84 & &
\end{tabular}

(c) International Prestige (Treiman, forthcoming) Metr1c

\begin{tabular}{lccccc|rr} 
& FAED & FAOCC & EDUC & FJOB & OCC & Mean & Std. Dev. \\
Father's education & - & .392 & .419 & .276 & .228 & 2.49 & 1.61 \\
Father's occupation & .357 & - & .340 & .284 & .303 & 41.54 & 13.10 \\
R's education & .505 & .259 & - & .437 & .454 & 3.69 & 1.50 \\
R's first job & .241 & .229 & .423 & -- & .389 & 36.74 & 11.19 \\
R's current occupation & .236 & .248 & .358 & .406 & - & 43.70 & 13.14 \\
$\quad$ Mean & 2.54 & 40.14 & 3.26 & 36.75 & 42.52 & &
\end{tabular}


Table 6 : Standardized and Metric Regression Coeffictents for Three-Equation Stratification Model, Australian Men Aged 20 and Over, 1965, by Selected Scales of Socioeconomic Status and Prestige

Dependent Variable Independent Variables

\begin{tabular}{llllll}
\hline $\begin{array}{l}\text { Father's } \\
\text { Education }\end{array}$ & $\begin{array}{l}\text { Father's } \\
\text { Occupation }\end{array}$ & Education & $\begin{array}{c}\text { First } \\
\text { Occupation }\end{array}$ & $\alpha$ & $\mathrm{R}^{2}$ \\
\hline
\end{tabular}

\section{STANDARDIZED COEFFICIENTS}

A. Duncan SES Scores

1) Education $\begin{array}{ll}.448 & .120 \\ (.022) & (.022)\end{array}$

2) First Occupation

$-.003$

.131

.458

.263

3) Current Occupation

$(.024)$

(.022)

(.023)

.375

$$
(.022)
$$

.103

$(.020)$

.299
$(.023)$

.344

(.021)

.375

B. Siegel Prestige Scores

$\begin{array}{lll}1) \text { Education } & .492 & .026 \\ & (.021) & (.021)\end{array}$

2) First Occupation

$$
\begin{aligned}
& -.015 \\
& (.024)
\end{aligned}
$$

(.022)

.430

(.023)

3) Current Occupation .001

.121
$(.021)$

.309

(.024)

.278

$(.022)$

\section{Treiman Prestige Scores}
1) Education
.487
$(.021)$
.049
(.021)

2) First Occupation

$$
\begin{aligned}
& .009 \\
& (.025)
\end{aligned}
$$

$.106^{\circ}$

(.022)

.375

$(.024)$

.172

3) Current Occupation .024

$(.024)$

.121

$(.021)$

.212

$(.025)$

.271

$(.022)$

\section{METRIC REGRESSION COEFFICIEITS}

A. Duncan SES Scores
4) Education
.455
-.054
.008
.140
7.27
1.83
5) First Occupation -.054
.115
4.96
.359
2.20
B. Siegel Prestige Scores
4) Education
.500
.003
5) First Occupaion $\quad-.138$
.116
6) Current Occupacion .011
.133
3.83
2.94
1.85
16.4
C. Treiman Prestige Scores
4) Education
.495
.005
5) First Occupation . .087
.104
6) Current Occupation
.258
.132
3.50
1.76
21.1

$\begin{array}{lll}2.22 & .305 & 18.3\end{array}$

\footnotetext{
${ }^{a}$ Standard errors in parenthesis.
} 
Table 7': Standardized and Metric Regression Coefficients for Three-Equation Stratification Model, U.S. Men Aged 20-64, March 1962, by Selected Scales of Socioeconomic Status and Prestige

Dependent Independent Variables

Variables

\begin{tabular}{|c|c|c|}
\hline & Ind & endent \\
\hline $\begin{array}{l}\text { Father's } \\
\text { Education }\end{array}$ & $\begin{array}{l}\text { Father's } \\
\text { Occupation }\end{array}$ & Education \\
\hline
\end{tabular}

\section{A. Duncan SES Scores}
1) Education

$$
309
$$
$(.007)^{a}$
.272
$(.007)$

2) First Occupation

.040
$(.007)$

.210

.405

(.007)

First
ccupation

.376
$(.007)$

.292

.113

(.007)

$(.006)$

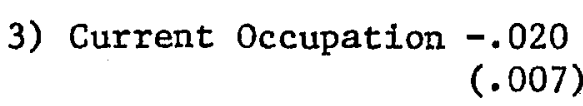

B. Siegel Prestige Scores

1) Education

.414
$(.007)$

.085

(.007)

.204

2) First Occupation

$$
\begin{aligned}
& .080 \\
& (.007)
\end{aligned}
$$

.093

(.007)
.415
(.007)

.240

3) Current Occupation -.014

$$
(.007)
$$
.100
$(.006)$

.367
$(.007)$

.253

$(.007)$

.401

C. Treiman Prestige Scoreso
1) Education
.417
$(.006)$
.092
(.006)
2) First Occupation
$(.083$
.109
$(.007)$
.374
(.007)
3) Current Occupation -.005
$(.007)$
.126
(.006)
.328
$(.007)$
.203
$(.007)$

.206

.317

METRIC REGRESSION COEFFICIENTS

A. Duncan SES Scores
4) Education
.311
.023
.226
.129
5.25
2.08
6) Current Occupation -.284
5.17
1.20
B. Siegel Prestige Scores
4) Education
.417
.013
.110
.120
3.14
1.98
6) Current Occupation -..106
2.84
15.3
C. Treiman Prestige Scores
4) Education
.419
.012
5) First Occupation .592
.103
.141
2.64
1.94
6) Current Occupation -.045
2.73
20.8

\footnotetext{
${ }^{a}$ Standard errors in parenthesis.
} 
Table 8 : Standardized and Metric Regression Coefficients for Three-Equation Stratification Mode1, Australian Men Aged 20- and Over in 1965 with Nonfarm Background and U.S. Men Aged 20-64 in 1962 with Nonfarm Background

Dependent

Variables

\begin{tabular}{llllll}
\multicolumn{7}{c}{ Independent Variables } \\
Father's & Father's & & \\
Education & Occ SES & Education First & & \\
\end{tabular}

\section{STANDARDIZED COEFFICIENTS}

A. Australia
1) Education
.454
$(.025)^{a}$
.109
.264
2) First Occ $\operatorname{SES}^{\mathrm{b}}$
$-.016$
$(.028)$
(.025)
.024
$(.026)$
.129
(.026)
.461
(.026)
.258
.104
.281
$(.027)$
.354
$(.024)$
.366

B. United States

1) Education

.303

(.008)

.234

(.008)

2) First Occ SES

.054
$(.008)$

.154

.405

.265

3) Current Occ SES

$(.008) \quad(.008)$

$(.008)$

.393

.104

.395

.286

$(.007)$

$(.008)$

$(.008)$

METRIC REGRESSION COEFFICIENT

\section{A. Australia}
4) Education
5) First Occ SES
.457
.007
.137
$-.250$
.116
7.23
1.86
6) Current Occ SES
.403
4.63
3.08
4.51

\section{B. United States}
4) Education
.282
.018
.165
5.62
2.37
5) First Occ SES
.696
.116
5.69
2.08
5.80

${ }^{a}$ standard errors in parenthesis.

$b$

Duncan SES scores assigned to all occupations, classified in major groups. 
Table 9: Standardized Regression Coefficients for Stratification Model Based on Figure 1, U.S. and Australian Men in 1962 and 1965, Respectively

\begin{tabular}{|c|c|c|c|c|c|c|}
\hline \multirow{2}{*}{$\begin{array}{l}\text { Dependent } \\
\text { Variables }\end{array}$} & \multirow{2}{*}{ FAED $^{a}$} & \multicolumn{3}{|c|}{ Independent Variables } & \multirow{2}{*}{$\mathrm{R}^{2}$} & \multirow{2}{*}{$\sqrt{1-R^{2}}$} \\
\hline & & FAOCC STATUS & EDUC & FJOB STATUS & & \\
\hline \multicolumn{7}{|l|}{ AUSTRALIA, 1965} \\
\hline$R^{\prime}$ s Education & $\frac{.489}{(.022)^{b}}$ & $\begin{array}{l}.104 \\
(.022)\end{array}$ & & & .298 & .838 \\
\hline FIrst Job Status & $\begin{array}{l}-.026 \\
(.025)\end{array}$ & $\begin{array}{c}.129 \\
(.022)\end{array}$ & $\begin{array}{l}.487 \\
(.023)\end{array}$ & & .280 & .849 \\
\hline $\begin{array}{r}\text { Current Occ } \\
\text { Status }\end{array}$ & $\begin{array}{l}.011 \\
(.023)\end{array}$ & $\begin{array}{l}.101 \\
(.021)\end{array}$ & $\begin{array}{l}.324 \\
(.024)\end{array}$ & $\begin{array}{l}.330 \\
(.021)\end{array}$ & .382 & .786 \\
\hline \multicolumn{7}{|l|}{ UNITED STATES, 1962} \\
\hline R's Education & $\begin{array}{l}.340 \\
(.007)\end{array}$ & $\begin{array}{l}.265 \\
(.007)\end{array}$ & & & .279 & .849 \\
\hline First Job Status & $\begin{array}{l}.036 \\
(.007)\end{array}$ & $(.180)$ & $\begin{array}{l}.433 \\
(.007)\end{array}$ & & .312 & .829 \\
\hline $\begin{array}{r}\text { Current Occ } \\
\text { Status }\end{array}$ & $\begin{array}{l}-.029 \\
(.007)\end{array}$ & $\begin{array}{l}.095 \\
(.006)\end{array}$ & $\begin{array}{l}.414 \\
(.007)\end{array}$ & $\begin{array}{l}.268 \\
(.007)\end{array}$ & .406 & .771 \\
\hline
\end{tabular}

a

See text for definition of variables.

Standard errors in parenthesis. 
Tab1e 10: Canonical Weights on First and Second Variates of Occupations, Based on

Intergenerational and Intragenerational Mobility Matrices, 1965 Australian and 1962 U.S. Men

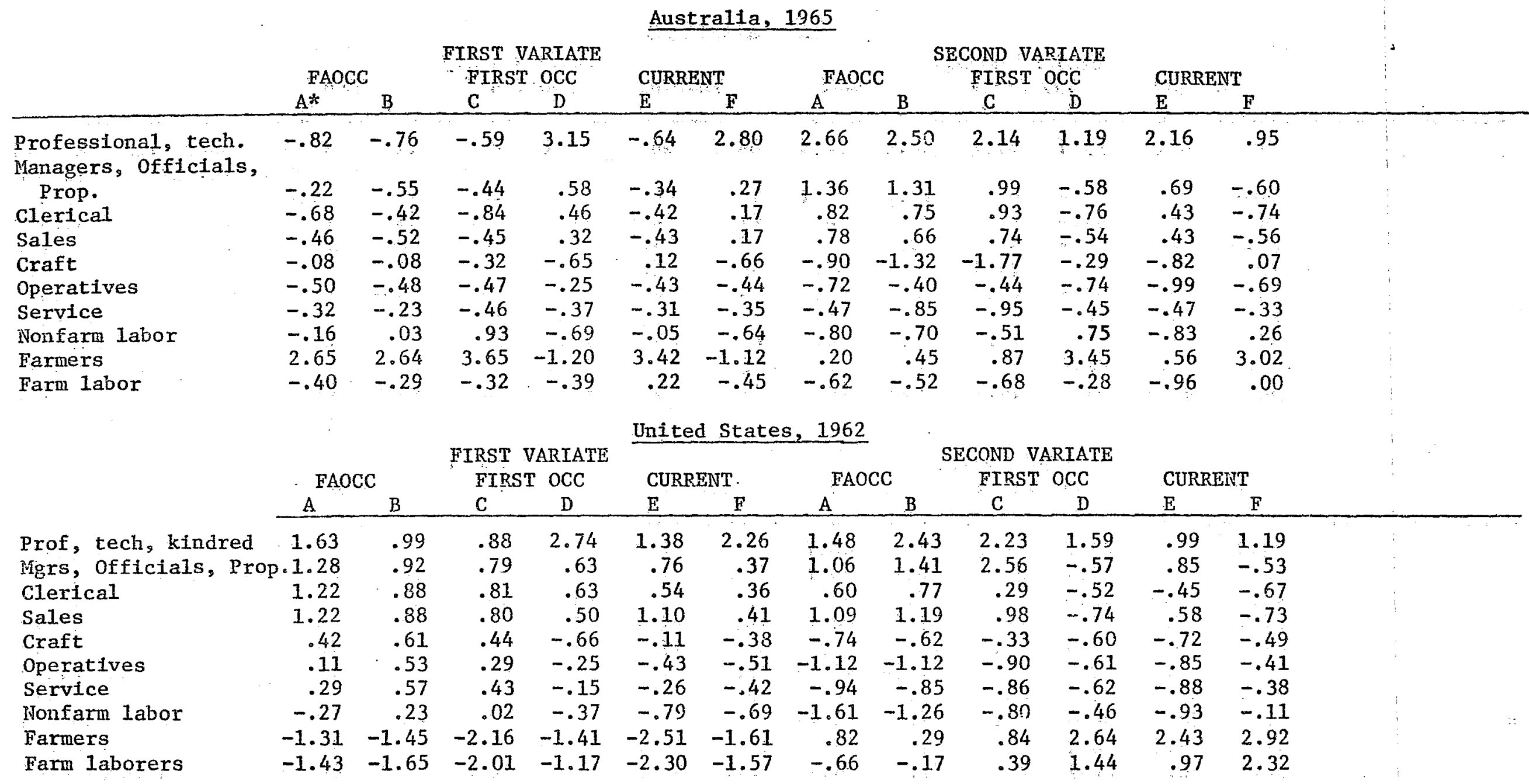

$\begin{array}{clcl}\text { *Column: } & \text { From } & \text { Column: } & \text { From: } \\ \text { A } & \text { Father to current matrix } & \text { D } & \text { First to current matrix } \\ \text { B } & \text { Father to first matrix } & \text { E } & \text { Father to current matrix } \\ \text { C } & \text { Father to first matrix } & \text { F } & \text { First to current matrix }\end{array}$


Table 11: Canonical Veights on First Variate of Occupations, Based on Intergenerational and Intragenerational Ilobility Matrices, 1965 Australian and 1962 U.S. Men of Nonfarm Origins

\begin{tabular}{|c|c|c|c|c|c|c|c|c|c|c|c|c|}
\hline \multirow{3}{*}{$\begin{array}{l}\text { Occupation } \\
\text { Groups }\end{array}$} & \multicolumn{6}{|c|}{ Australia, 1965} & \multicolumn{6}{|c|}{ United States, 1962} \\
\hline & \multicolumn{2}{|c|}{ FAOCC } & \multicolumn{2}{|c|}{ FIRST OCC } & \multicolumn{2}{|c|}{ CURRENT } & \multicolumn{2}{|c|}{ FAOCC } & \multicolumn{2}{|c|}{ FIRST OCC } & \multicolumn{2}{|c|}{ CURRENT } \\
\hline & $A^{*}$ & B & $\mathrm{C}$ & D & $\mathbf{E}$ & $\mathbf{F}$ & A & B & $\mathrm{C}$ & $\mathrm{D}$ & E & $\mathbf{F}$ \\
\hline Prof, tech, kindred & 2.17 & 2.09 & 1.81 & 2.81 & 1.84 & 2.46 & 1.72 & 2.07 & 2.00 & 2.76 & 1.37 & 2.24 \\
\hline $\begin{array}{l}\text { Managers, off, } \\
\text { Prop. }\end{array}$ & $1.19^{\circ}$ & 1.16 & .98 & .42 & .67 & .14 & 1.30 & 1.27 & 2.37 & .35 & 1.05 & 1.32 \\
\hline c1erical & .59 & .71 & .85 & .32 & .32 & .09 & .95 & .74 & .41 & .33 & .00 & .07 \\
\hline Sales & .71 & .62 & .76 & .24 & .42 & .08 & 1.25 & 1.11 & .98 & .16 & .99 & .10 \\
\hline Craft & -.98 & -1.30 & -1.58 & -.86 & -.99 & -.81 & -.34 & -.40 & -.18 & -.37 & -.62 & -.61 \\
\hline Operatives & -.68 & -.17 & -.23 & -.50 & -1.01 & -.69 & -.81 & -.84 & -.76 & -.55 & -1.02 & -.71 \\
\hline Service & -.37 & -.79 & -.73 & -.53 & -.47 & -.52 & -.57 & -.60 & -.67 & -.48 & -.86 & -.59 \\
\hline Nonfarm laborers & -.88 & -.86 & -1.02 & -.65 & -.95 & -.72 & -1.41 & -1.15 & -.86 & -.63 & -1.40 & -.80 \\
\hline
\end{tabular}

$\begin{array}{cl}\text { *Column: } & \text { From: } \\ \text { A } & \text { Father to current matrix } \\ \text { B } & \text { Father to first matrix } \\ \text { C } & \text { Father to first matrix } \\ \text { D } & \text { First to current matrix } \\ \text { E } & \text { Father to current matrix } \\ \text { F } & \text { First to current matrix }\end{array}$


Table 12: Canonical Correlations Among Occupation Variates, Australian and U.S. Mobility Matrices

TOTAL MEIT

\begin{tabular}{|c|c|}
\hline & Australia \\
\hline Occupations & $\begin{array}{ll}\text { First } & \text { Second } \\
\text { Variate: } & \text { Variate }\end{array}$ \\
\hline
\end{tabular}

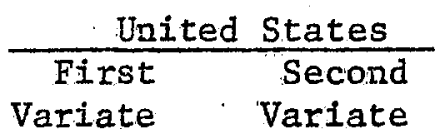

Father and Current Occ

$$
.491
$$

.316

.423

.263

Father and First Occ

.459

.271

.564

.297

First and Currest Occ

.628

.494

.570

.428

\section{NONFARII ORIGIN}

$$
\begin{aligned}
& \text { First } \\
& \text { Variate }
\end{aligned}
$$

Father and Current Occ

Father and First Occ

First and Current $0 c c$

$$
.337
$$

.312

.636

\section{First \\ Variate}

.348

.341

.549

Source: Tables 10 and 11. 
Table 13: Correlations of Occupational Variates Between U.S. and Australia

First Variate, TOTAL MEN

$\begin{array}{ll}\text { FAOCC } & \text { A* } \\ \text { FIRST OCC } & \text { B } \\ & \text { C } \\ \text { CURREIT } & \text { D } \\ & \text { E } \\ & \text { F }\end{array}$

Second Variate, TOTAL NEN

FAOCC

A

B

FIRST OCC

CURRENT
$A *$

C

F
Correlation Coefficient

.60

.66

.69

.96

.73

.93

First Variate, Nonfarm Orfgin

FAOCC

FIRST OCC

CURRENT
A

B

C

D

E
.89

.93

.73

.82

.32

.80

Source: Tables 10 and 11 .

$\begin{array}{cl}\text { *Row: } & \text { From: } \\ \text { A } & \text { Father to current matrix } \\ \text { B } & \text { Father to first matrix } \\ \text { C } & \text { Father to first matrix } \\ \text { D } & \text { First to current matrix } \\ \text { E } & \text { Father to current matrix } \\ \text { F } & \text { First to current matrix }\end{array}$

.93

.92

.82

.99

.92

.92 
Table 14:8 Correlations of Canonical Weights and Status Scores for Major Occupation Groups, Australia. and U.S. Men

\begin{tabular}{cccc} 
Duncan & Siegel & Duncan & Siegel \\
SES & Prestige & SES & Prestige \\
TOTAL NEN & NONFARM ORIGIN \\
\hline
\end{tabular}

Australia

First Variate FAOCC $\quad A^{*}$

FAOCC B

.38

.44

FIRST OCC $C$

.44

.86

FIRST OCC
CURRENT

. .41

CURRENT

.84

.13

.15

.15

.01

.16

$-.02$

Second Variate FAOCC

- FAOCC

FIRST OCC

FIRST OCC

CURRENT

CURRENT
.90

.83

.84

.14

.93

.17
.15

.02

.01

.21

.18

.22
.94

.89

.86

.86

.94

.85
.84

.80

.73

.82

.83

.81

\section{United States}

\section{First Variate}

FAOCC

FAOCC

FIRST OCC C

FIRST OCC D

CURREINT E

CURRENT F

.87

.65

.64

.89

.84

.92

.80

.89

.78

.06

.21

.27

Second Variate FAOCC A

FIRST OCC

FIRST OCC

CURRENT

CURRENT

$\begin{array}{lll}\mathrm{A} & .80 & .22 \\ \mathrm{~B} & .89 & .25 \\ \mathrm{C} & .78 & .25 \\ \mathrm{D} & .06 & .17 \\ \mathrm{E} & .21 & .25 \\ \mathrm{~F} & .27 & .19\end{array}$

Source: Tables 10 and 11 .

*Row:

A
B
C
D
E
F
From:

Father to current matrix

Father to first matrix

Father to first matrix

First to current matrix.

Father to current matrix

First to current matrix
.03

.17

.14

.02

.04

.01

.97

.99

.85

.88

.88

.94

.85

.87

.85

.91

.25

.19 
Table A.1: Son's Current Occupation by Father's Current (or Last) Occupation, Australian Men Aged 20 and Older: 1965

Father's Major Occupation Group
Son's Major Occupation Group: Current Occupation

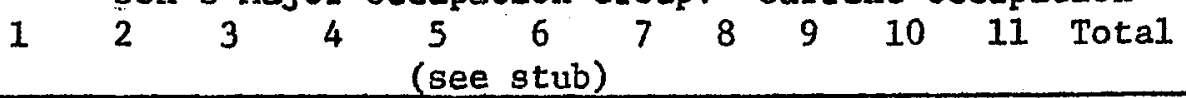

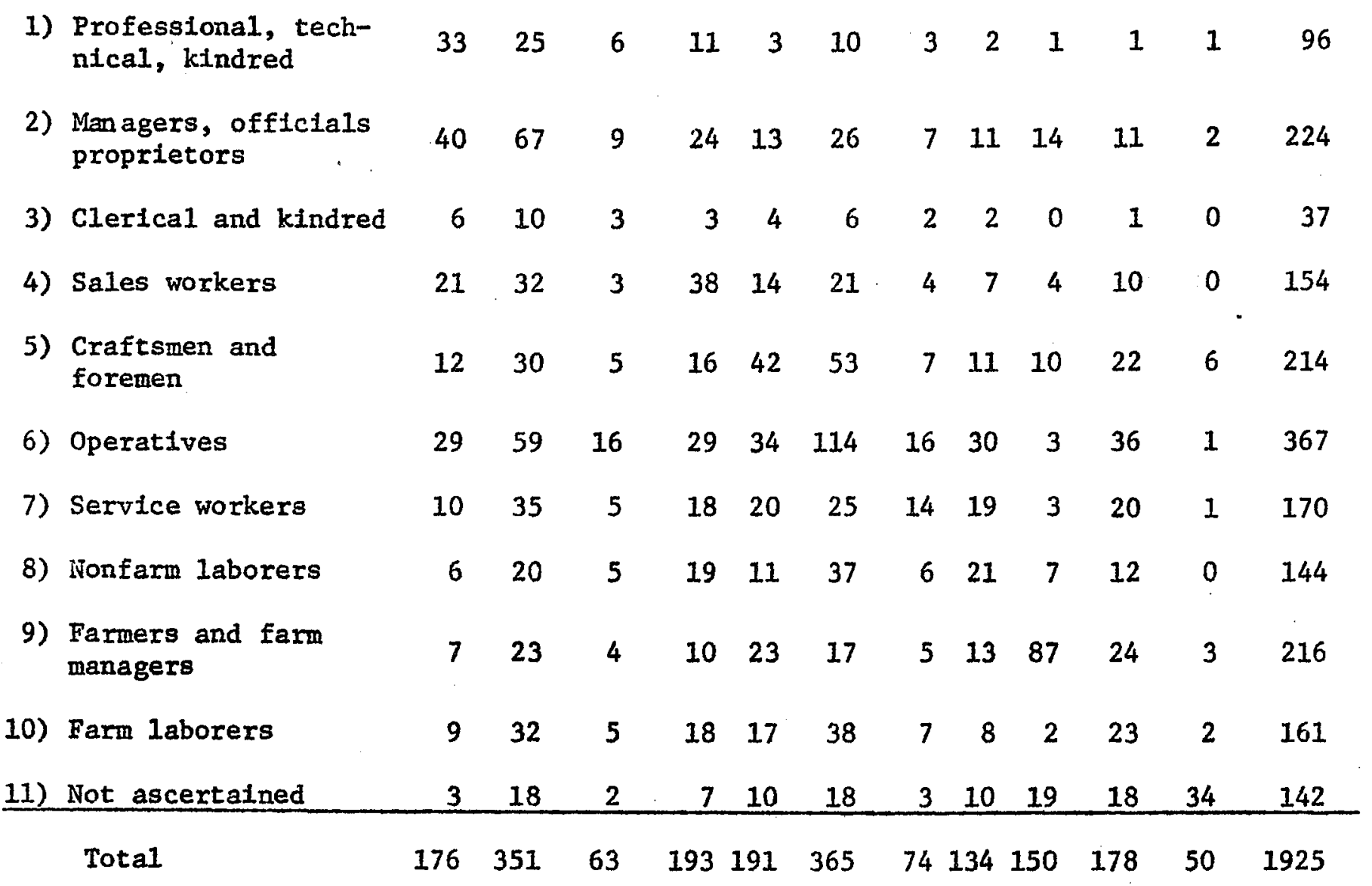


Table A.2: Son's First Full-time Occupation by Father's Current (or Last) Occupation, Australian Men Aged 20 and Older: 1965

Father's Major Occupation Group
Son's Major Occupation Group: First Occupation

$\begin{array}{llllllllllll}1 & 2 & 3 & 4 & 5 & 6 & 7 & 8 & 9 & 10 & 11 \text { Total }\end{array}$ (see stub)

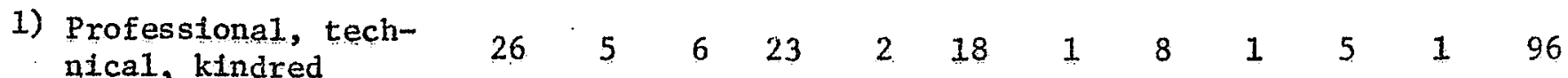

2) Managers, offictals proprietors

$\begin{array}{llllllllllll}32 & 26 & 7 & 57 & 13 & 43 & 5 & 23 & 4 & 13 & 1 & 224\end{array}$

$\begin{array}{lllllllllllll}\text { 3) Clerical and kindred } & 2 & 7 & 4 & 4 & 1 & 9 & 1 & 5 & 1 & 3 & 0 & 37\end{array}$

$\begin{array}{lllllllllllll}\text { 4) Sales workers } & 10 & 13 & 3 & 55 & 11 & 29 & 6 & 18 & 2 & 7 & 0 & 154\end{array}$

5) Craftsmen and foremen

$\begin{array}{llllllllllll}12 & 8 & 5 & 30 & 52 & 44 & 3 & 40 & 7 & 12 & 1 & 214\end{array}$

6) Operatives

$\begin{array}{llllllllllll}25 & 21 & 8 & 55 & 28 & 130 & 16 & 44 & 6 & 33 & 1 & 367\end{array}$

7) Service workers

$\begin{array}{llllllllllll}10 & 11 & 2 & 23 & 15 & 32 & 21 & 38 & 1 & 16 & 1 & 170\end{array}$

8) Nonfarm laborers

$\begin{array}{llllllllllll}4 & 3 & 6 & 24 & 7 & 33 & 2 & 46 & 1 & 13 & 0 & 144\end{array}$

9) Farmers and farm managers

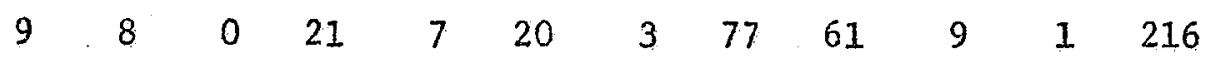

10) Farm Laborers $\begin{array}{llllllllllll}6 & 8 & 4 & 34 & 18 & 38 & 2 & 17 & 6 & 27 & 1 & 161\end{array}$

11) Not ascertained

$\begin{array}{lllllllllllll}0 & 3 & 1 & 9 & 7 & 24 & 3 & 30 & 1 & 10 & 54 & 142\end{array}$

Total

$136 \quad 11$

$\begin{array}{llll}46 & 335 & 161 & 425\end{array}$

$\begin{array}{llllll}63 & 346 & 91 & 148 & 61 & 1925\end{array}$ 
Table A.3: Son's Current Occupation by First Full-time Occupation, Australian Men Aged 20 and Older: 1965

First Major Occupation Group
Son's Current Major Occupation Group

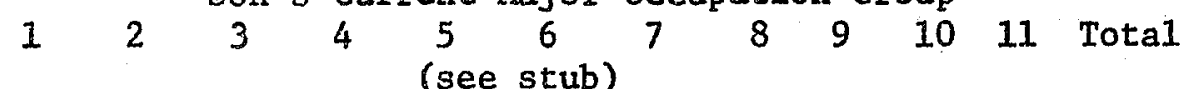

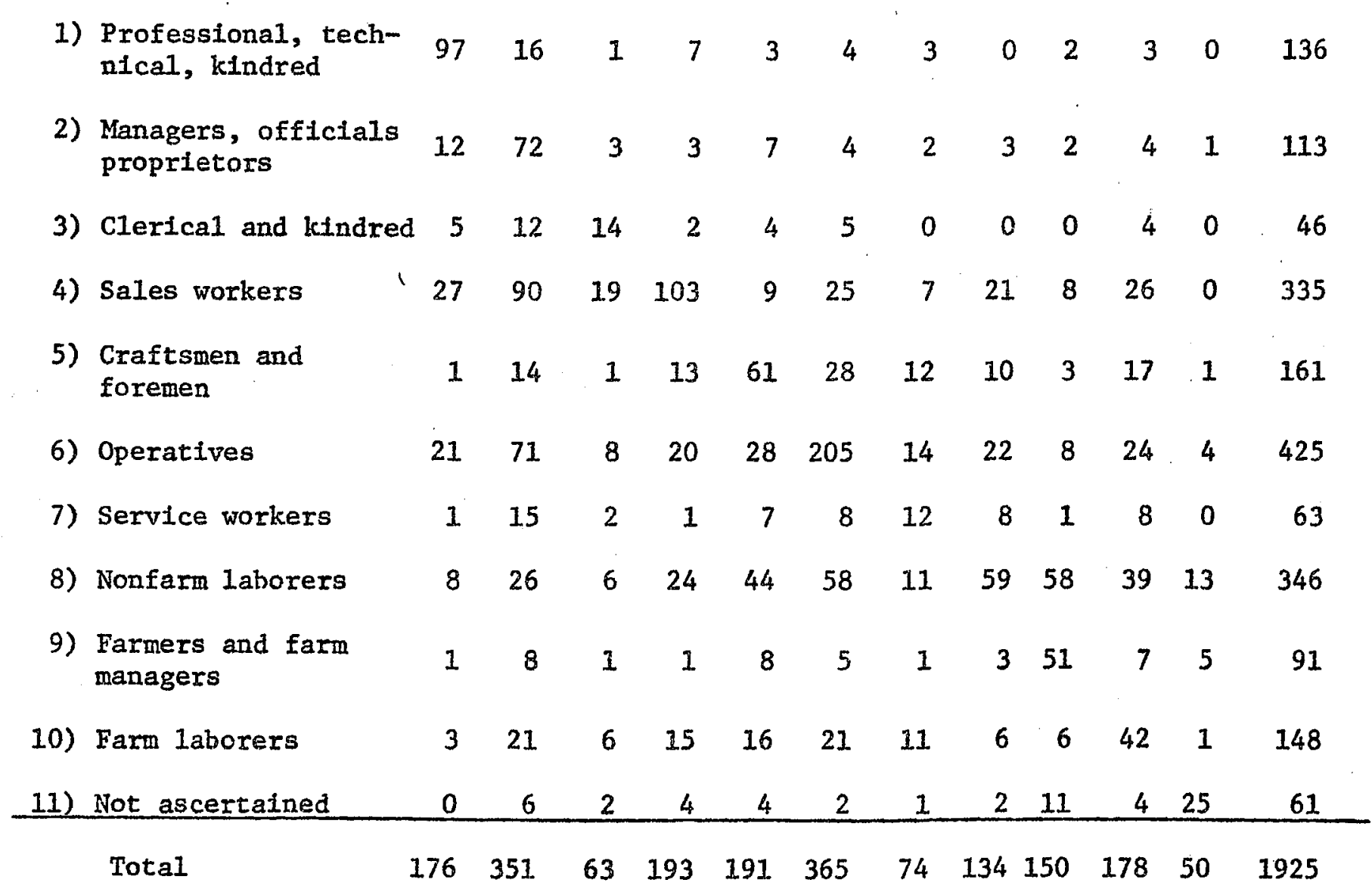


REFEREIVCES

Bilau, P. M. and O. D. Duncan

1967 The American Occupational Structure. New York: Wiley.

Broom, L. and F. L. Jones

1969 "Career mobility in three societies." American Sociological Review 34:650-658.

Duncan, $0 . D$.

1961 "A socioeconomic index for all occupations." Pp. 109-138 in

A. J. Reiss, et al. Occupations and Social Status. New York:

Free Press.

Duncan, O. D., D. L. Featherman, and B. Duncan

1972 Socioeconomic Background and Achievement. New York: Seminar. Duncan-Jones, $\mathrm{P}$.

1972 "Social mobility, canonical scoring, and occupational classification." Pp. 191-210 in J. Goldthorpe and K. Hope (eds.) The Analysis of Social Mobility: Methods and Approaches. Oxford: Clarendon.

Fararo, T.

1973 Mathematical Sociology. Wew York: Wiley-Interscience.

Featherman, D. L., R. M. Hauser and W. H. Sewe11

1974 "Toward comparable data on inequality and stratification." The American Sociologist 9:18-25.

Goldthorpe, J. and K. Hope

1972 "Occupational grading and occupational prestige." Pp. 19-80 in Goldthorpe and Hope (eds.) The Analysis of Social Mobility: Methods and Approaches. Oxford: Clarendon. 
Goldthorpe, J. and $\mathrm{K}$. Hope

Forth- The Social Grading of Occupations: A New Approach and Scale. coming Oxford: Clarendon.

Goodman, L.

1969 "How to ransack social mobility tables and other kinds of cross-classification tables." American Journal of Sociology $75: 1-40$.

1972 "A general model for the analysis of surveys." American Journal of Sociology $77: 1035-1086$.

Haller, A. O. and A., Portes

1973 "Status attainment processes." Sociology of Education 46:51-91. Hodge, R. M., P. Siege1, and P. Rossi

1966 "Occupational prestige in the United States: 1925-1963." Pp. 322-334 in R. Bendix and S. M. Lipset, Class, Status, and Power. New York: Free Press.

Hodge, R. M., D. Treiman, and P. Rossi

1966 "A comparative study of occupational prestige." Pp. 309-321

in R. Bendix and S. M. Lipset, Class, Status, and Power. New York: Free Press.

Jencks, C.

1972 Inequality. New York: Basic Books.

Jones, F. L.

1971 "Occupational achievement in Australia and the United States." American Journal of Sociology 77:527-539.

Jöreskojg, K., G. Gruvaeus, and M. van Thillo

1970 "ACOVS: a general computer program for the analysis of covariance structures." Research bulletin RB-70-15, Educational Testing Service, Princeton, N.J. 
Klatzky, S. and R. Hodge

1971 "A canonical correlation analysis of occupational mobility."

Journal of the American Statistical Association 66:16-22.

MeFarland, D.

1969 "Measuring the permeability of occupational structures." American Journal of Sociology 75:41-61.

1970 "Intra-generational social mobility as a Markov process." American Sociological Review 35:463-476.

Parkin, F.

1971 Class Inequality and Political Order. New York: Praeger. Pease, J., W. Form, and J. Rytina

1970 "Ideological currents in American stratification 1iterature." The American Sociologist 5:127-137.

Reiss, A.

1961. Occupations and Social Status. New York: Free Press.

Sewe11, W. H. and R. M. Hauser

1972 "Causes and consequences of higher education: models of the status attainment process." American Journal of Agricultural Economics $54: 851-861$.

Sewel1, W. H., A. O. Haller, and G. Ohlendorf

1970 "The educational and early occupational status attainment process." American Sociological Review 35:1014-1027.

Siegel, $P$.

1970 "The American occupational prestige structure." Ph.D. dissertation. University of Chicago. 
44

Siegel, $P$. and $R$. Hodge

1968 "A causal approach to measurement error." Pp. 28-59 in H. M. Blalock and A. B. Blalock (eds.) Methodology in Social Research. New York: McGraw.

S $\phi$ renson, A.

1973 "Attainment and opportunity." Unpublished paper, Institute for

Research on Poverty, University of Wisconsin, Madison.

Svalastoga, $K$.

1972 "The determination of occupational prestige." Unpublished

paper. Copenhagen, Denmark.

Titmuss, $R$.

1962 Income Distribution and Social Change. London: G. Allen \& Unwin, Ltd. Trefman, D.

Forth- Occupational Prestige in Comparative Perspective. New York: coming Seminar.

Weber, M.

1958 "Class, status, and party." In H. Gerth and C. W. Mills (eds.)

From Max Weber. New York: Oxford.

White, H.

1970 Chains of Opportunity. Cambridge, Mass.: Harvard University

Press. 